\title{
INCREASING ACCURACY VALUE IN THE ESTIMATES OF CARBON STOCK BY USING VEGETATION INDEX FROM ALOS AVNIR 2 SATELLITE IMAGERY
}

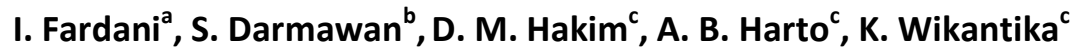 \\ ${ }^{a}$ Bandung Islamic University (UNISBA), Indonesia \\ ${ }^{b}$ National Institute of Technology (ITENAS), Indonesia \\ ${ }^{c}$ Bandung Institute of Technology, Indonesia
}

Article Info:

Received: 8 January 2016 In revised form: 5 February 2016 Accepted: 28 April 2016

Available Online: 30 April 2016

\section{Keywords:}

Accuracy value, carbon stock, vegetation index, ALOS AVNIR, Meru Betiri

\section{Corresponding Author:} Irland Fardani

Bandung Islamic University, Bandung, Indonesia Email: irlan128@gmail.com

\begin{abstract}
The existence of carbon stock began to be noticed by the public, especially after the global warming phenomenon, because one of the causes of global warming is the increasing amount of carbon in the atmosphere. There are several approaches that can be used to calculate carbon stocks, one of which is through remote sensing. In the study of carbon stocks in Meru Betiri National Park Indonesia, the vegetation index from ALOS-AVNIR satellite imagery is used to estimate carbon reserves by finding an exact equation. If it uses the Modified Soil Adjusted Vegetation Index (MSAVI) only, the correlation value is 0.49. Meanwhile, if Infrared Percentage Vegetation Index (IPVI) is used, the correlation value is 0.47 . However, if some vegetation indices such as SoilAdjusted Vegetation Index (SAVI), Normalize Difference Vegetation Index (NDVI) and Ratio Vegetation Index (RVI) are combined, the correlation value of the equation is 0.63 . The comparison showed that by combining several variables of vegetation indices will increase the value of the correlation equation significantly.
\end{abstract}

Copyright (C) 2016 GJGP-UNDIP This open access article is distributed under a Creative Commons Attribution (CC-BY-NC-SA) 4.0 International license.

\section{How to cite (APA 6th Style):}

Fardani, I., et. al. (2016). Increasing accuracy value in the estimates of carbon stock by using vegetation index from Alos Avnir 2 satellite imagery.Geoplanning: Journal of Geomatics and Planning, 3(1), 1-14. doi:10.14710/geoplanning.3.1.1-14

\section{INTRODUCTION}

Forests play an important role in absorbing $\mathrm{CO}_{2}$ from the atmosphere and keeping it function well. It has been concluded that $60 \%$ of carbon stock (C) is stored by the forest and about $40 \%$ is found in the soil. Land conversion, deforestation, forest degradation, and reforestation would alter the type of soil covering and therefore would cause the biomass and underground carbon composition to change (Elias \& Wistara, 2009). For that reason, it is important to quantify precisely every biomass composition from varied vegetation in the forest to determine the exact carbon absorption capacity. This quantification can only be calculated if the right methods and reliable data are used. Carbon storage and its absorption by forests are among of the most important natural processes to reduce $\mathrm{CO}_{2}$ concentration in the atmosphere.

There are several approaches that can be used to estimate carbon storage. Lu (2006), Cantarello et al. (2011), Sohl et al. (2012), Humpenöder et al. (2013), Akumu \& McLaughlin (2014), Ardiansyah and Buchori (2014), Sun et al. (2015), has reviewed and summarized some different approaches such as field measurement, remote sensing, and GIS based analysis for estimate carbon storage. Methodological approach using remote sensing has been successfully approved to measure carbon storage in low density boreal forests (Rosenqvist et al., 1999). Tropical forests have the richest carbon storage and complex structural ecosystems in the earth. Instrumental signal obtained from remote sensing is expected to be able to estimate areas tending to be saturated rapidly.

Biomass consists of two components, i.e., surface and underground biomass components (Hairiah et al., 2001). Surface biomass component is the biggest component from total biomass amount. One of the storage characteristics of tropical forests is that carbon storage proportion in surface biomass is far bigger than that in the underground (Ulumuddin et al., 2005). Carbon storage can be calculated by land coverage 
estimation approach or by remote sensing approach using vegetation index at every pixel that is statistically correlated with carbon storage. Likelihood error using land coverage estimation lies in the different state in every class at every landscape classification (Widayati et al. , 2005). Myeong et al. (2006) has developed a regression equation that can be used to estimate carbon storage in forests from Normalized Difference Vegetation Index (NDVI) obtained from Landsat satellite imaging and concluded the storage value resulted from NDVI estimation approached by carbon storage calculation derived from field measurement model. For a better result, satellite imaging with medium or high spatial resolution has been used to model the parameters from trees and land coverage structures. One of the satellite imaging used is ALOS AVNIR-2 (Lévesque \& King, 2003).

This study is aimed at estimating the correlation between carbon storage using vegetation index multivariable approach and ALOS AVNIR-2 Satellite Imaging in Meru Betiri National Park area (see flow chart in Figure 1 and sample location in Figure 2). From the scientific point of view, this study develops carbon storage estimation model based on vegetation index value obtained from ALOS AVNIR Satellite Imaging. Meanwhile, from practical point of view, it can be prior information for local legislators before dealing with carbon trading activities. Carbon storage is assessed by using correlation analysis between vegetation index value and spectral value from every satellite imaging band and carbon storage measurement in field.

Figure 1. Flow Chart of the Study (Authors, 2016)

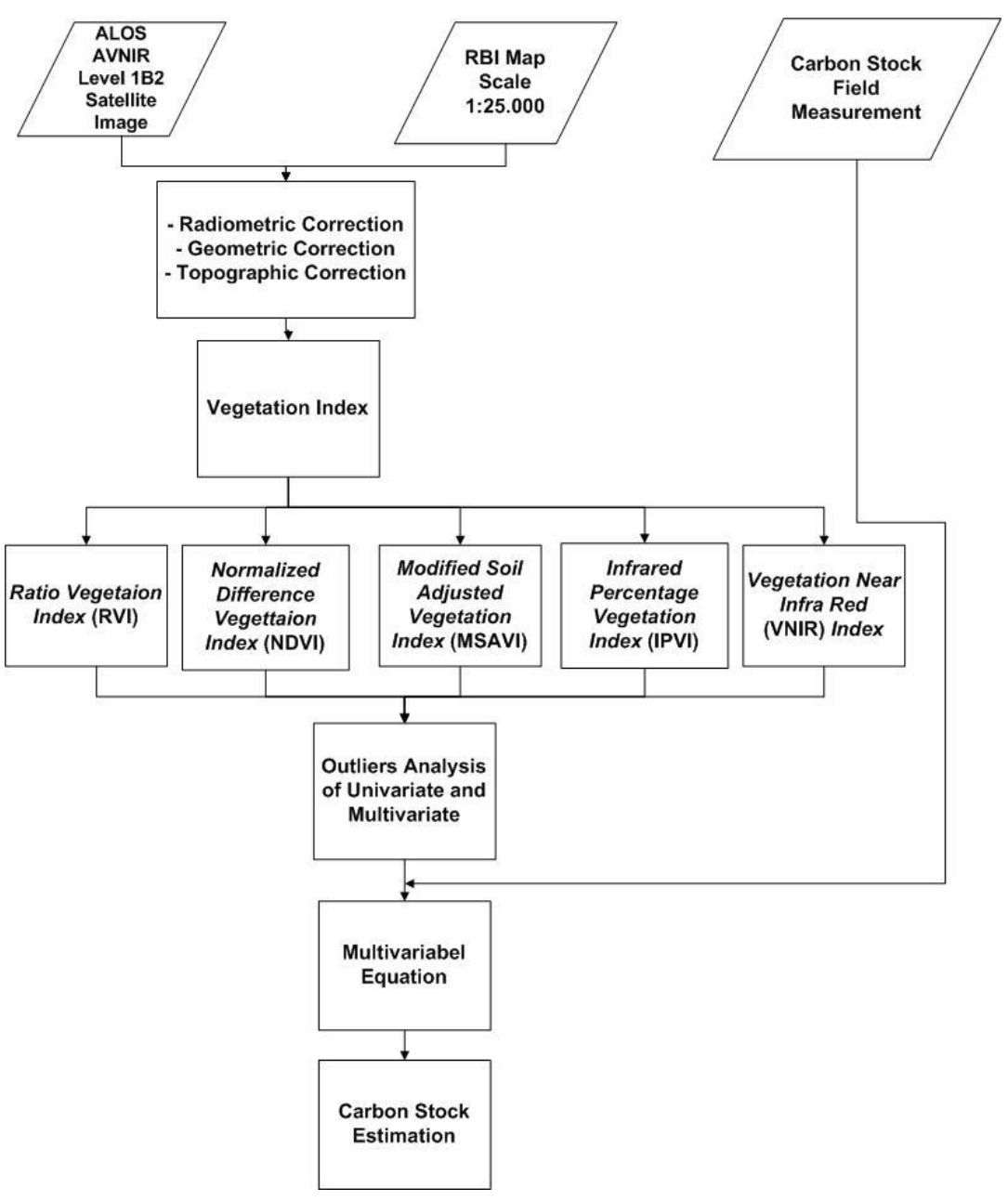

Advanced Visible and Near Infrared Radiometer Type 2 (AVNIR) is an extension version of the advanced Earth Observing Satellite (ADEOS). Imaging from the satellite has spatial resolution of 10 meters and 4 bands. The bands consist of red, green, blue, and infrared bands. The advantage of AVNIR-2 lies within the fourth band (infrared band). Moreover, AVNIR-2 can also be used to make land coverage map, soil humidity mapping, etc. 
Figure 2. Field Data Location and Sample Points (Authors, 2016)

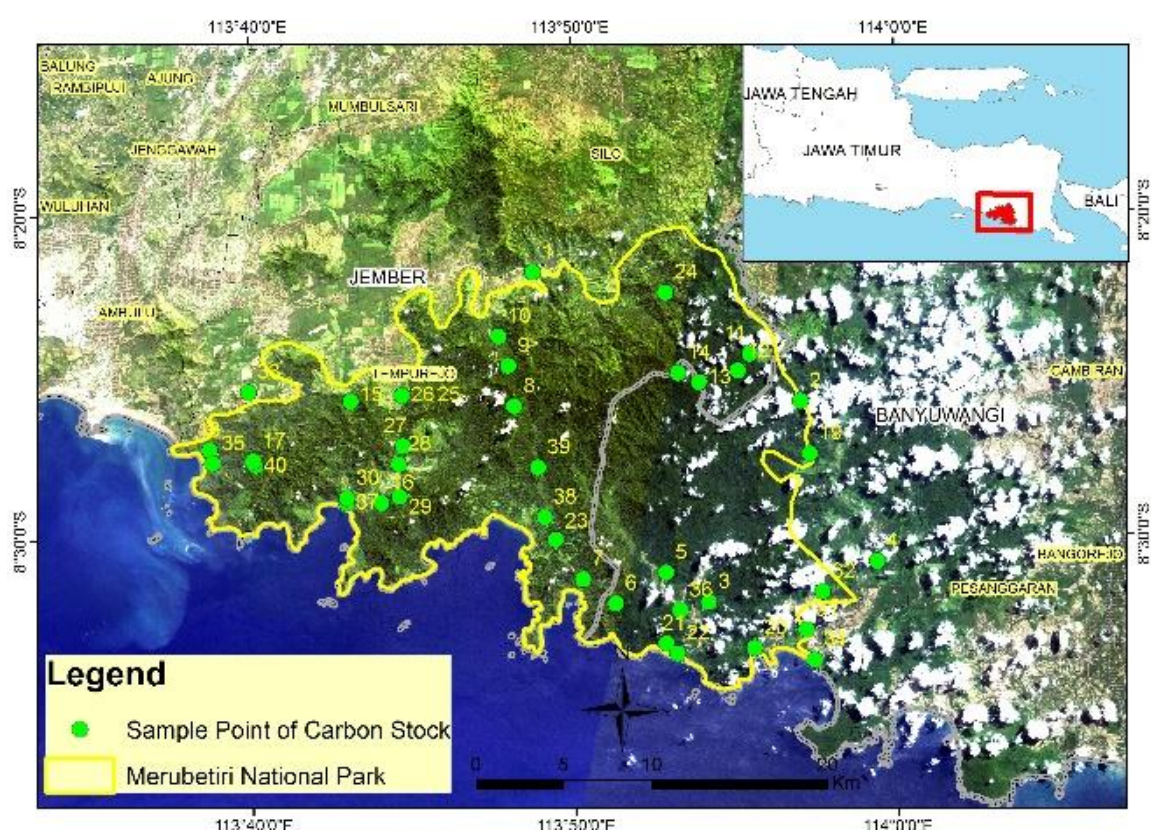

From field survey using allometric method, several parameters that could be used to calculate carbon stock were obtained. The parameters are trees height $(\mathrm{H})$, trees diameter, trees canopy diameter (Length $(\mathrm{L})$ and weight $(\mathrm{W})$, and the distance between soil and leaves $(\mathrm{Hc})$ like illustration in Figure 3 ).

Figure 3. The Illustration of Calculated Trees Part (Ponce-Hernandez, et. al., 2004)

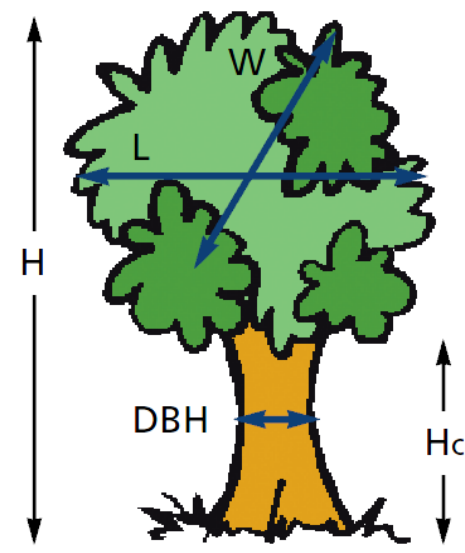

The steps involved: calculating basal area, volume and biomass with equation (1), (2), and (3) (PonceHernandez, et. al., 2004):

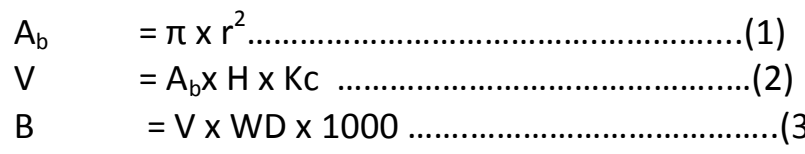

With :

$\pi \quad=3.14155927$

$r \quad=$ Radius from DBH (0.5 $\times$ DBH)

$\mathrm{A}_{\mathrm{b}} \quad=$ Basal Area

$\mathrm{H}=$ Trees Height

$\mathrm{Kc}=$ Constant Value (0.5463)

$\mathrm{V}=$ Volume

WD $=$ Wood Density 
Carbon storage values in every land coverage type were calculated using carbon conversion factor:

1. Carbon stored in primary forests $=$ biomass $X 50 \%$

2. Carbon stored in secondary forests and mangrove $=$ biomass $X 44.6 \%$

3. Carbon stored in agro forestry and plantation $=$ biomass $X 44 \%$

4. Carbon stored in bushes, pasture, and grassland $=$ biomass $X 42.9 \%$

Trees biomass and non tree vegetation biomass were calculated non-destructively whilst ground vegetation biomass and litters destructively. The plot of vegetation biomass calculation was rectangle of 20 $\mathrm{m} \times 100 \mathrm{~m}$ in shape. The division of subplots was adjusted with its own dimensions (see Figure 4).

Figure 4. The Section of Carbon Storage Data Samples (Ponce-Hernandez, et. al., 2004)

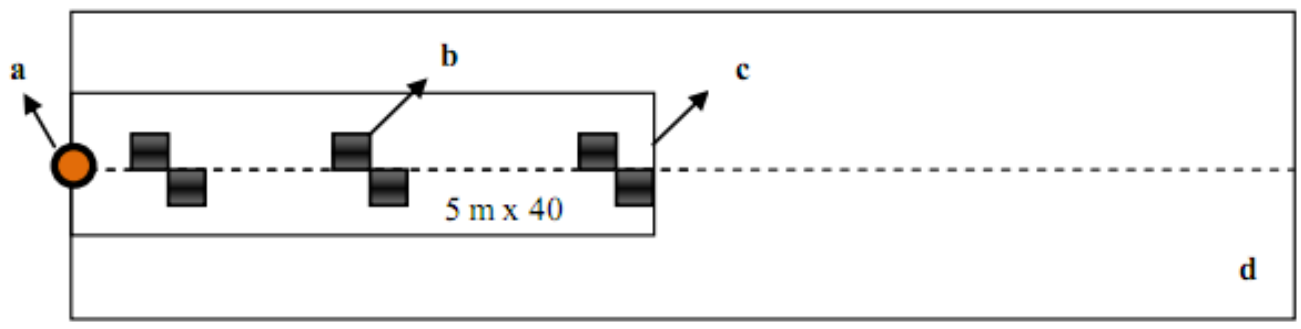

$20 \mathrm{~m} \times 100 \mathrm{~m}$

\section{DATA AND METHODS}

\subsection{Geometric Correction}

Geometric Correction was needed since there was a geometric distortion between ALOS AVNIR imaging and the object. Geometric distortion is the geometry imperfection recorded while imaging. This distortion causes the dimensions, positions, and imagery forms to become not exactly as what it is. The distribution of Independent control points shown in Figure 5. From previous calculation, RMSE value was $4.619 \mathrm{~m}$. This value complies the minimum standard of an error from imaging correction, which is half of its resolution value.

Figure 5. Distribution of Independent Control Points (Analysis, 2015)

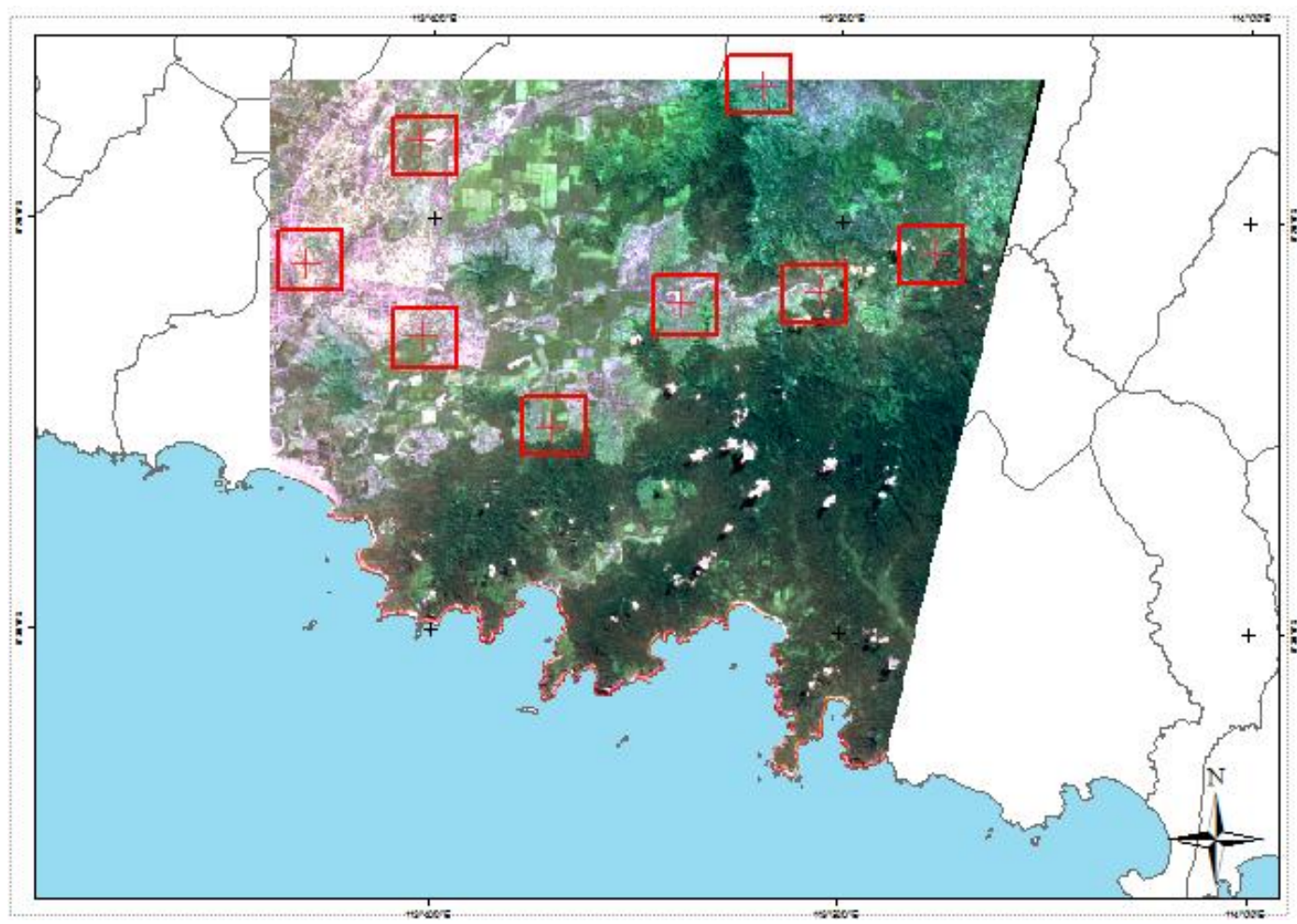




\subsection{Radiometric Correction}

Every Digital Number (DN) from every band of ALOS imaging was converted into physical measurement of radiance sensor (Figure 6 and 7). The spectral number of every satellite imaging band ALOS AVNIR-2 is shown in Figure 8.

Figure 6. Imaging of Band 1 and 2 Before and After Radiometric Correction (Analysis, 2015)
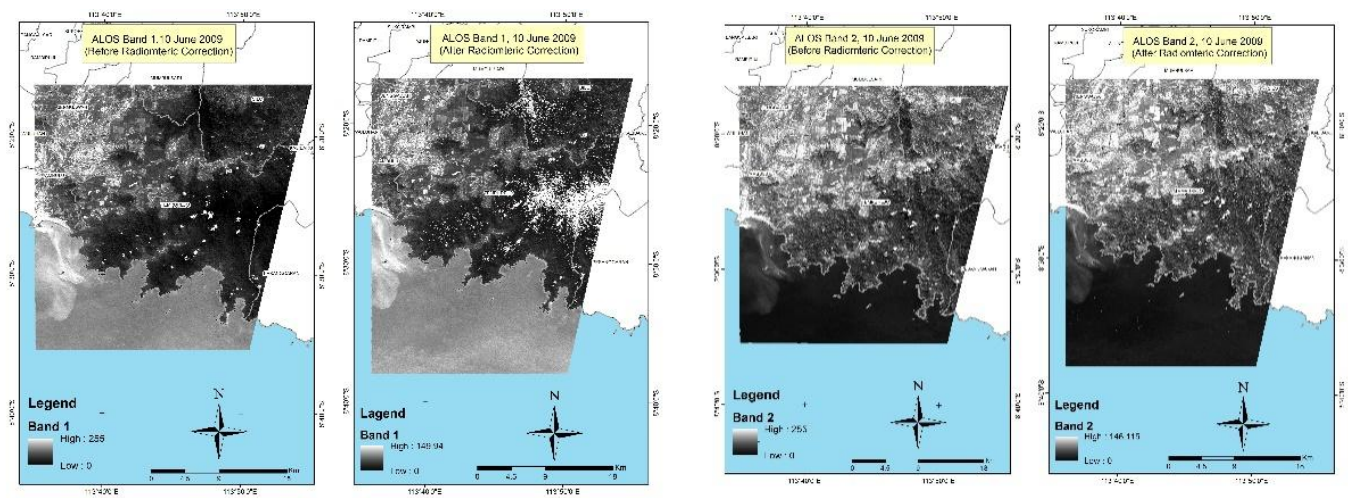

Figure 7. Imaging of Band 3 and 4 Before and After Radiometric Correction (Analysis, 2015)
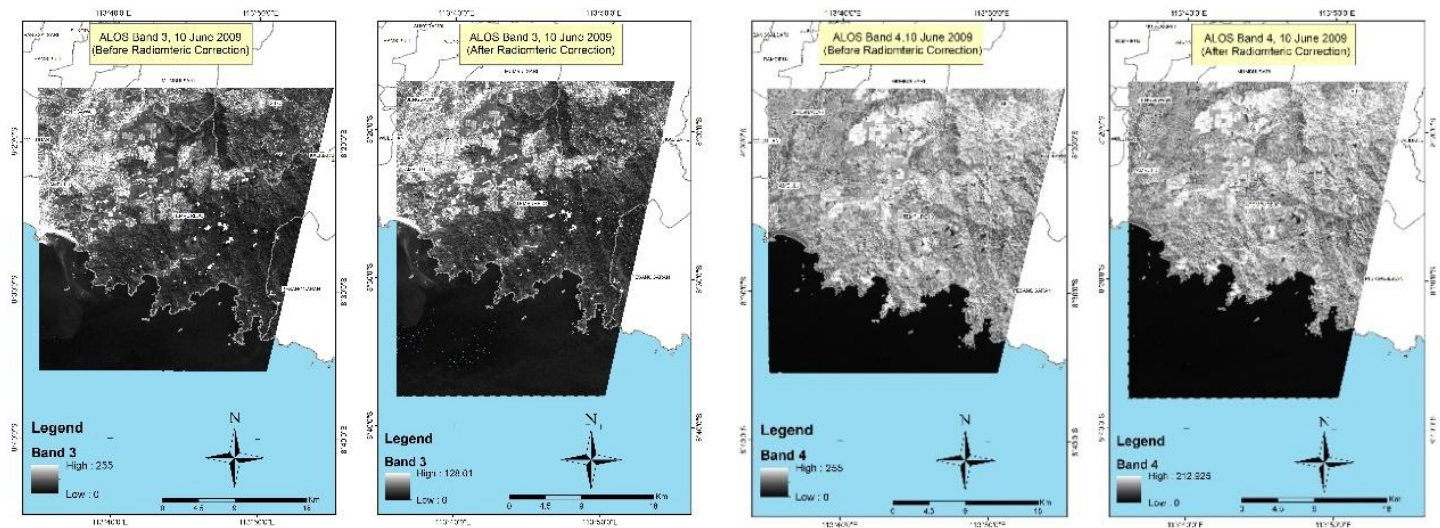

Figure 8. Spectral Number of Every Satellite Imaging Band ALOS AVNIR-2 (Analysis, 2015)
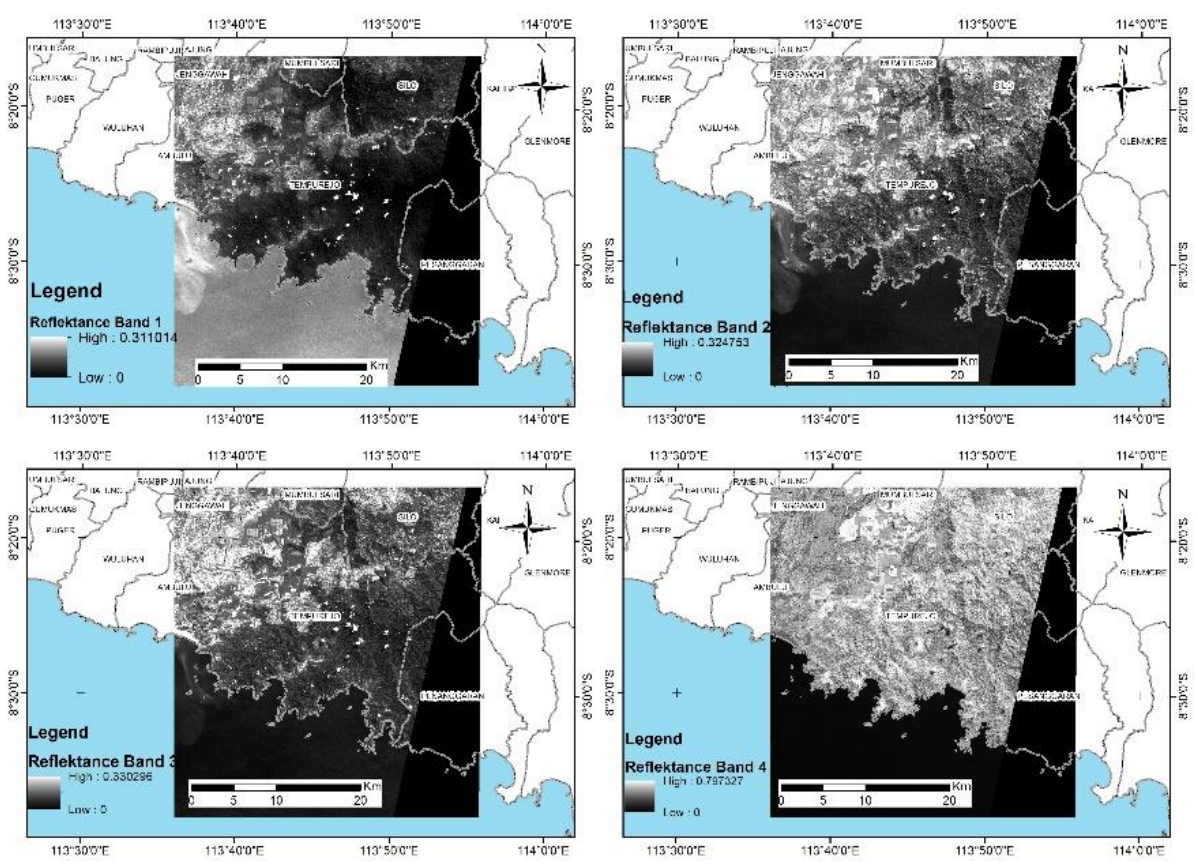


\subsection{Topographic Correction}

Topographic correction or topographic normalization must be done since a radiation difference due to irregular surface shape exists. This difference results in different reflectance values of every similar vegetation type. Shaded area gives low reflectance values whilst sun exposed area gives high reflectance values. The first step in topographic correction is to find the parameter called Illumination (IL) using equation (4)(Sularso et al., 2011). The topographic correction is shown in Figure 9.

$$
\mathrm{IL}=\cos \Theta_{\mathrm{p}} \cos \Theta_{\mathrm{z}}+\sin \Theta_{\mathrm{p}} \sin \Theta_{\mathrm{z}} \cos \left(\phi_{\mathrm{a}}-\phi_{\mathrm{o}}\right) \ldots .(4)
$$

With:

$\Theta_{\mathrm{p}} \quad=$ Solar Angle

$\Theta_{z} \quad=$ Solar Zenit Angle

$\phi_{\mathrm{a}} \quad=$ Solar Azimuth Angle

$\phi_{0} \quad=$ Aspect Angle

One of the applications using Illumination model value is in topographic correction that used Lambertian method in equation 5 .

$$
\mathrm{p}_{\mathrm{H}} \quad=\mathrm{p}_{\mathrm{T}}+\left[\mathrm{pT} \frac{\mathrm{ILm}-\mathrm{IT}}{\pi \mathrm{Lm}}\right] .
$$

With:

$\rho_{\mathrm{H}} \quad=$ Reflectance value on flat surface

$\rho_{\mathrm{T}} \quad=$ Reflectance value from wavy surface

IL = Illumination value

$\mathrm{IL}_{\mathrm{m}} \quad=$ The average of Illumination value

Figure 9. Before (left) and After (right) Topographic Correction Image (Analysis, 2015)

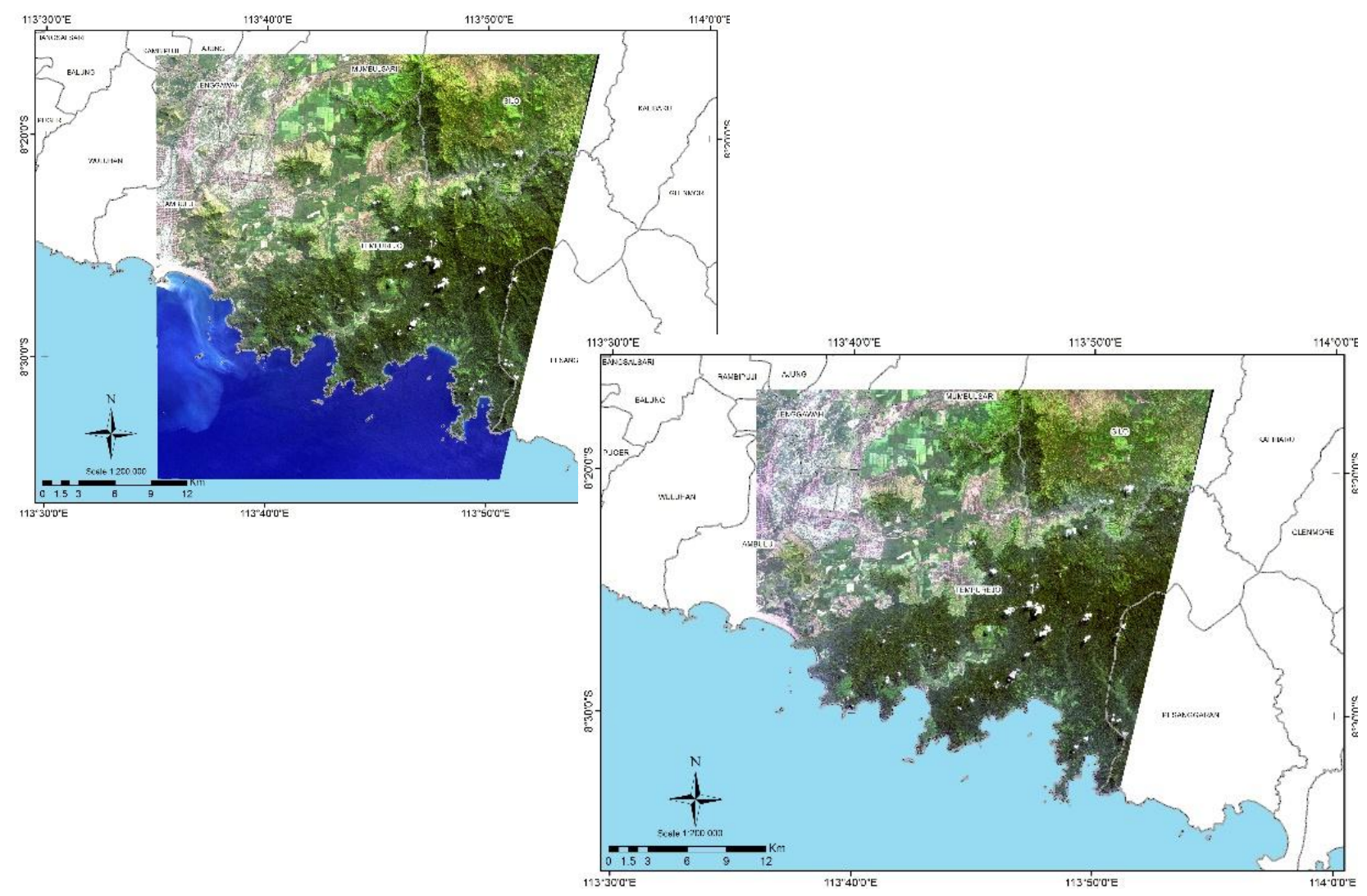




\subsection{Cloud Masking}

Another source of errors in satellite imaging processing is cloud coverage in the study area. Cloud coverage causes error because the digital number in that area would be high, thus, the cloud should be omitted. This process is called cloud masking and the results are shown in Figure 10, Figure 11, and Figure 12 as follows.

Figure 10. RVI and NDVI Distribution Map (Analysis, 2015)

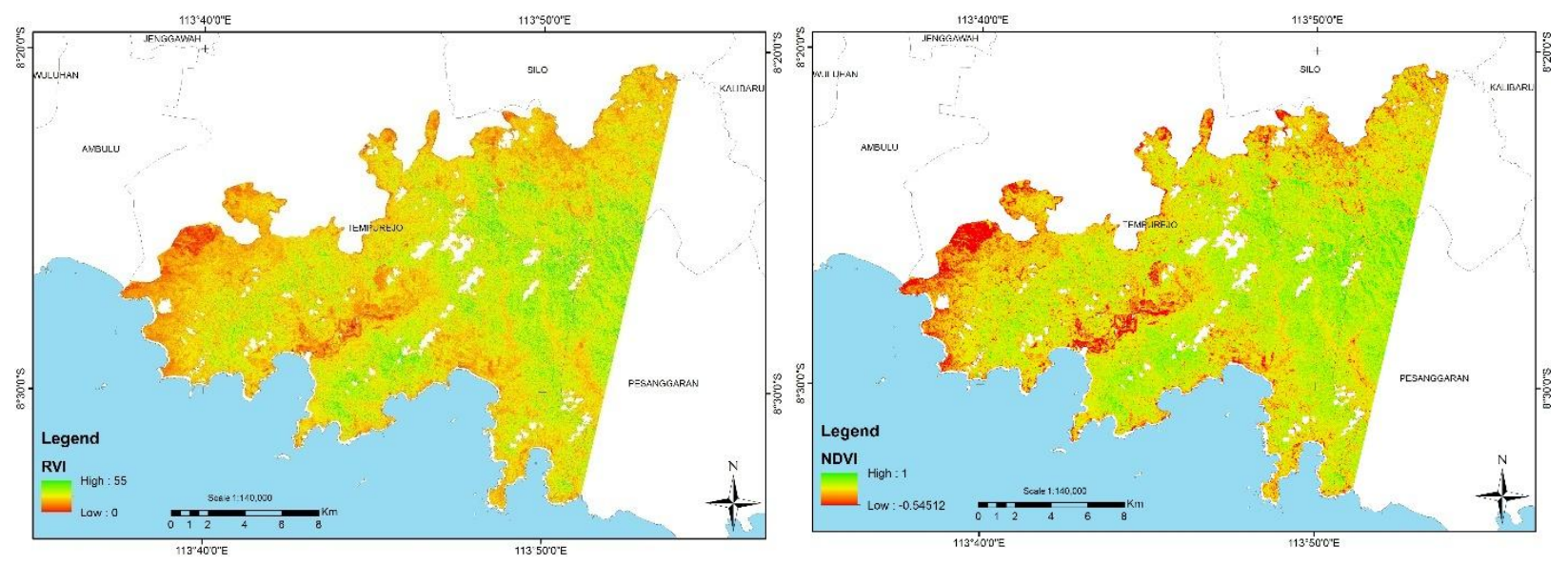

Figure 11. IPVI and MSAVI Distribution Map (Analysis, 2015)
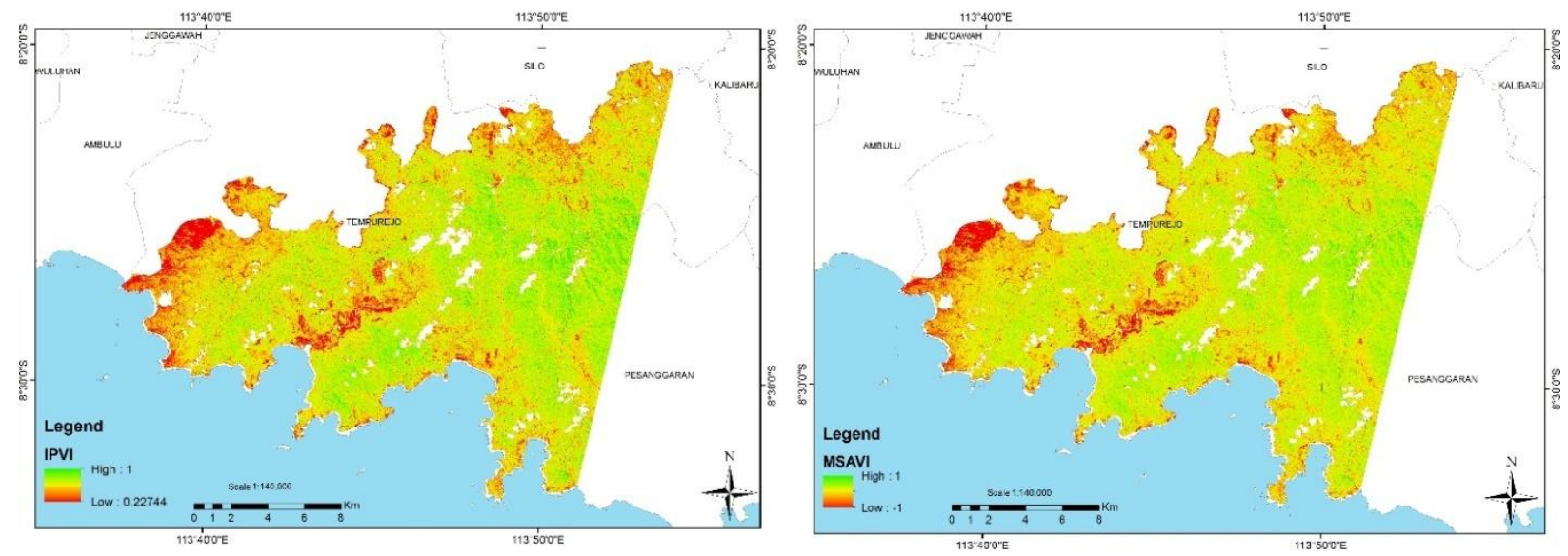

Figure 12. VNIR Distribution Map (Analysis, 2015)

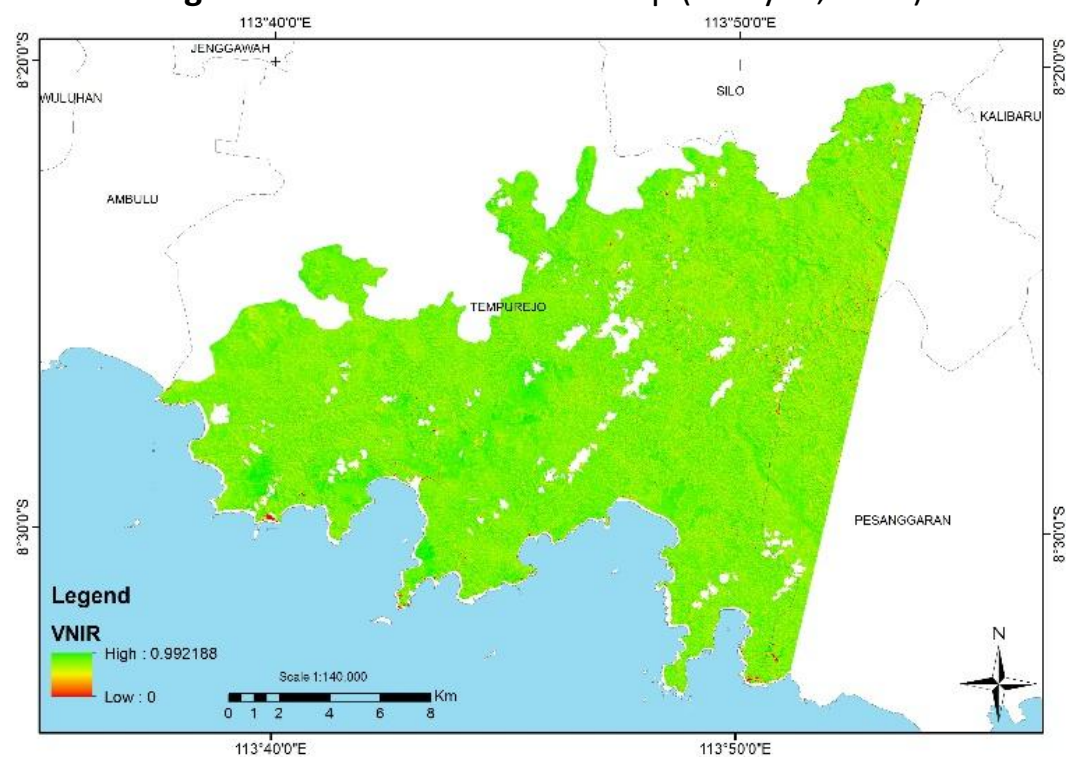




\subsection{Outliers Data Selection}

Outlier is an observation that is far beyond other observations. Generally, outliers can be classified into 4 categories based on its causes, as follows:

1) Procedural error

2) Unusual occurrence with explanation

3) Unusual occurrence without explanation

4) Non-unusual occurrence but with unique combination.

Outliers can be evaluated with two methods, i.e., univariate outlier and multivariate outlier analyses.

\section{a. Univariate Outliers}

Univariate Outlier can be discovered by determining threshold value that would be categorized as outliers. It is calculated by converting observation data value into standard score, which is usually called zscore, which has an average value of zero deviation standard of 1 . Observation data with z-score $>3.0$ would be categorized as outliers using equation 6 and 7 (Riaño et al., 2003).

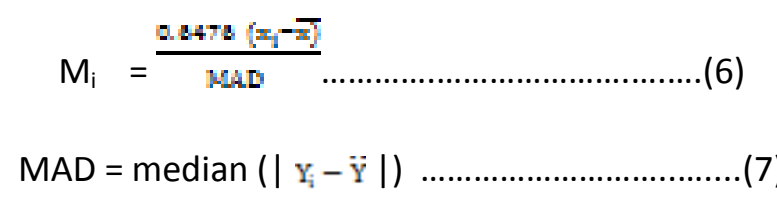

With :

$\mathrm{Xi}=$ Data

$\mathrm{X}=$ Median Data

$\mathrm{Y}_{\mathrm{i}}=$ Data

$\widehat{\mathrm{Y}}=$ Median

\section{b. Multivariate Outliers}

Multivariate outliers need to be determined because, even though data that is being analyzed show no outliers in univariate level, observations that have been done can be outliers if they have been combined with pixel number from vegetation index. The Mahalanobis Distance for every observation can be calculated and will determine the distance of an observation from the average number of all variables in a multidimensional space. Mahalanobis system gives population a tool to know whether data samples belong to some populations. Mahalanobis Distance, by considering correlation structure among the inputs using equation 8, will generate a feasible combination of data collection (Filzmoser, 2004; Seo, 2006).

$$
\lambda^{x}=(\mathrm{x}-\mu)^{-2} \Delta^{-2}(\mathrm{x}-\mu) \text {. }
$$

With:

$\mathrm{Xi}=$ Data

$X \quad=$ Median Data

$\mathrm{Y}_{\mathrm{i}}=$ Data

$\widehat{\mathrm{Y}}=$ Median

\section{RESULTS AND DISCUSSION}

\subsection{Multivariate Outliers}

From the correlation between every vegetation index and field measurement data, an exponential equation can be made to approach carbon storage number (Table 1). The results are shown in Figure 13, Figure 14, and Figure 15. 
Figure 13. Plots of Pixel RVI \& NDVI with Carbon Storage Data (Analysis, 2015)
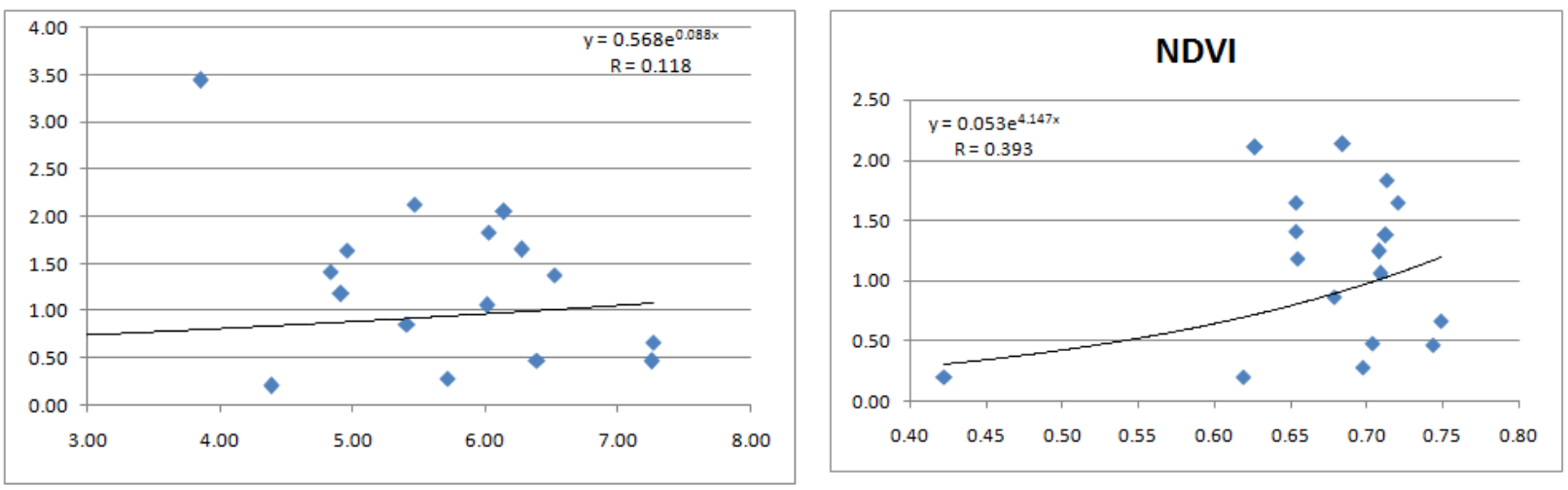

Figure 14. Plots of Pixel MSAVI \& IPVI with Carbon Storage Data (Analysis, 2015)
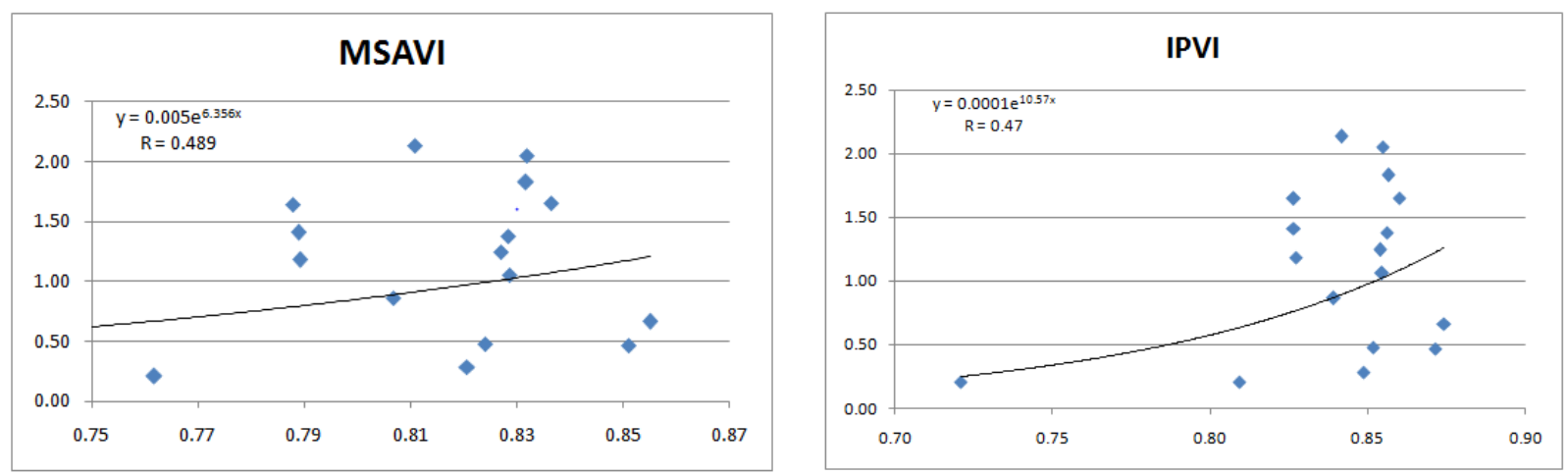

Figure 15. Plots of Pixel VNIR Value with Carbon Storage Data (Analysis, 2015)

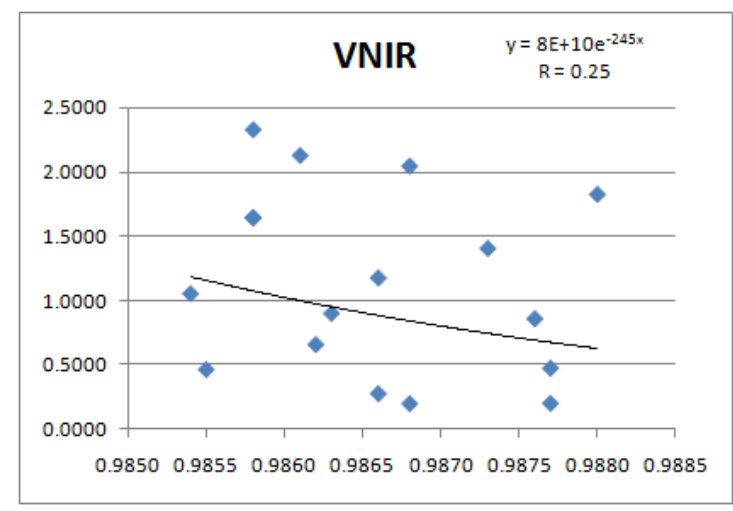

Table 1.The Correlation and Estimation of Carbon Storage from Every Vegetation Index (Analysis, 2015)

$\begin{array}{cccc}\text { No. } & \text { Vegetation Index } & \text { Correlation } & \text { Carbon Storage Estimatio } \\ \mathbf{1} & \text { NDVI } & 0.393 & 4,239,054 \\ \mathbf{2} & \text { MSAVI } & 0.489 & 3,328,197 \\ \mathbf{3} & \text { IPVI } & 0.47 & 3,009,540 \\ \mathbf{4} & \text { RVI } & 0.118 & 3,426,446 \\ \mathbf{5} & \text { VNIR } & 0.25 & -\end{array}$




\subsection{Multivariable Equation}

From those five vegetation indices that had been analyzed, in order to form a linear equation, the most influential vegetation index to carbon storage value was chosen using Stepwise method. The result showed that vegetation indices of MSAVI, RVI, and NDVI, play significant role (see Table 2).

Table 2. The Correlation Resulted from Stepwise Method (Analysis, 2015)

\begin{tabular}{ccccc} 
Model & $\mathbf{R}$ & R Square & Adjusted R Square & Std. Error of the Estimate \\
\hline $\mathbf{1}$ & $.350^{\mathrm{a}}$ & 0.122 & 0.064 & 0.6217 \\
$\mathbf{2}$ & $.477^{\mathrm{b}}$ & 0.227 & 0.117 & 0.60391 \\
\hline $\mathbf{3}$ & $.632^{\mathrm{c}}$ & 0.4 & 0.261 & 0.55236 \\
\hline
\end{tabular}

a. Predictor : (Constant), MSAVI

b. Predictor : (Constant), MSAVI, RVI

c. Predictor : (Constant), MSAVI, NDVI

The linear regression equation obtained was Carbon Storage $=41.0621-(199.068 \times \mathrm{MSAVI})+(197.383 \times$ $\mathrm{NDVI})-(2.43022 \times \mathrm{RVI})$ with correlation number of 0.63 . The carbon storage calculation with errors in occupied land coverage is shown in Figure 16.

Figure 16. Carbon Storage Calculation with Errors in Occupied Land Coverage (Analysis, 2015)

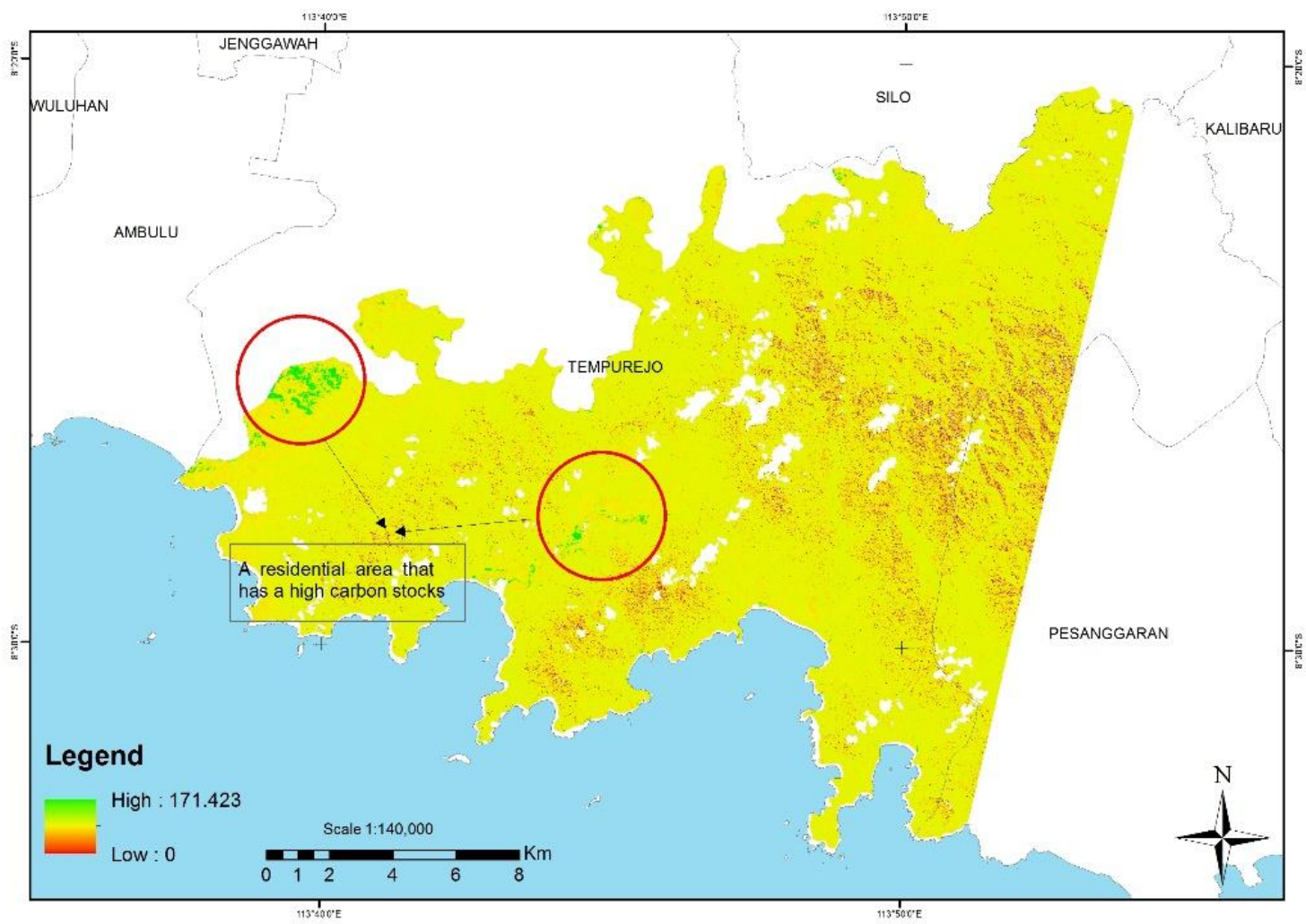

The result showed that carbon storage estimation value in occupied land coverage class was very high. Furthermore, it caused the occurrence of an error in the calculation of carbon storage estimation. The error came from pixel numbers of settled area that were pretty high due to considerably light reflection from rooftops. In order to minimize the error, settled should be omitted from carbon storage calculation. After land coverage of settled area was omitted from carbon storage calculation, the equation using 3 vegetation index variables resulted in a distribution map of carbon storage in almost $3 / 4$ area of Meru Betiri National Park (34,958 ha), was 3,591,321 Tons (see Figure 17). 
Figure 17. Distribution Map of Carbon Storage in Meru Betiri by Using Linear Equation (Analysis, 2015)

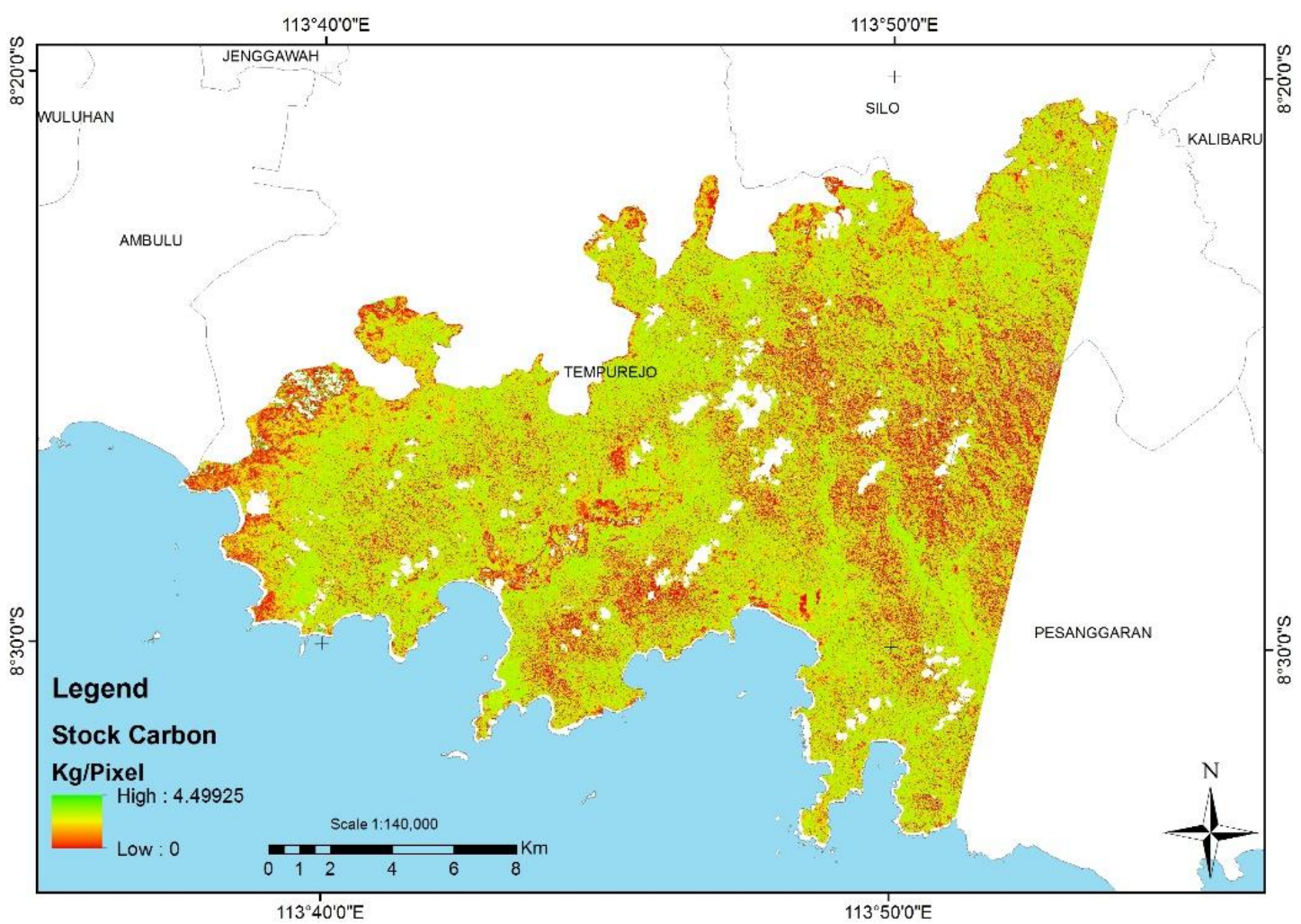

Thereafter, carbon storage estimation using exponential approach was done. Vegetation indices that were going to be used in multivariable exponential equation were selected based on the highest correlation number at single equation of vegetation index and carbon storage correlation. The chosen indices were MSAVI and IPVI. The equation resulted was Carbon Storage $=0.069 \times\left(\mathrm{e}^{(-235.894 \times \text { IPVI })}+\mathrm{e}^{(3.439 \times \mathrm{MSVI})}\right)$ with correlation number ( $r$ ) of 0.32. Therefore, the carbon storage was 3,921,323 tons (see Figure 18).

Figure 18. Distribution Map of Carbon Storage in Meru Betiri by Using Exponential Equation (Analysis, 2015)

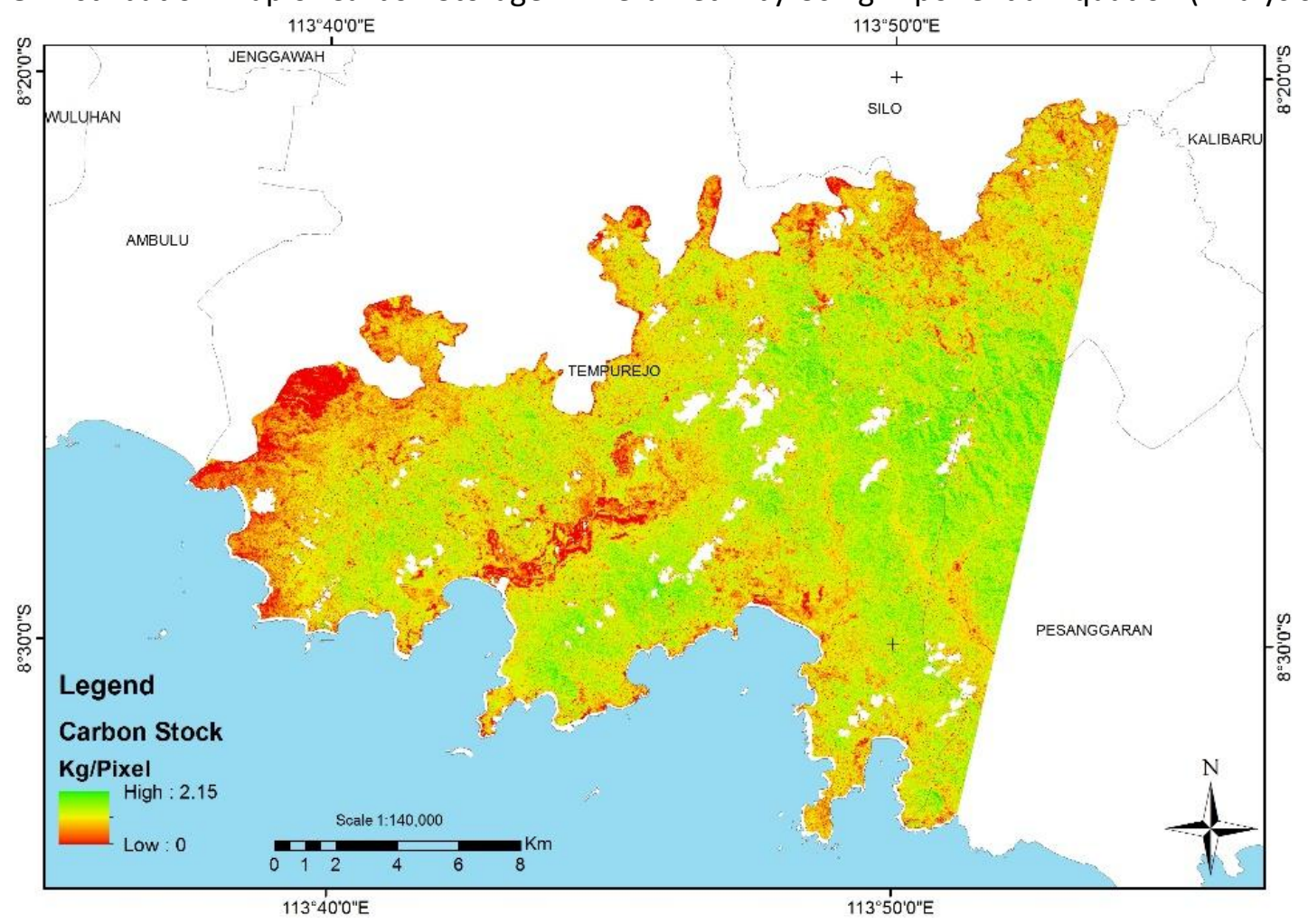


The correlations between land coverage classification and carbon storage coefficient in every land coverage are shown in Table 3. The total of carbon storage value by land coverage classification was $3,632,418$ tons. This result was not much different with the value resulted from carbon storage value using correlation of vegetation index and pixel number from satellite imaging approach. When compared with each other, the results were only different for about $1.1 \%$. The land cover classification is shown in Figure 19.

Table 3. Carbon Storage Calculation in Every Land Coverage (Analysis, 2015)

\begin{tabular}{rcrrr}
\hline No & Land Coverage & Area $(\mathrm{Ha})$ & Coefficient (Tons/Ha) & Carbon Storage (Tons) \\
\hline 1 & Primary Forests & $19,284.13$ & 120.93 & $2,332,030$ \\
\hline 2 & Secondary Forests & $10,323.85$ & 106.61 & $1,100,625$ \\
\hline 3 & Pastures & $1,758.98$ & 21.17 & 37,238 \\
\hline 4 & Bushes & $2,873.23$ & 32.28 & 92,748 \\
\hline 5 & Plantation & 727.15 & 95.96 & 69,777 \\
\hline & \multicolumn{2}{c}{ Total } & & $\mathbf{3 , 6 3 2 , 4 1 8}$ \\
\hline
\end{tabular}

Figure 19. Distribution of Land Use (Analysis, 2015)

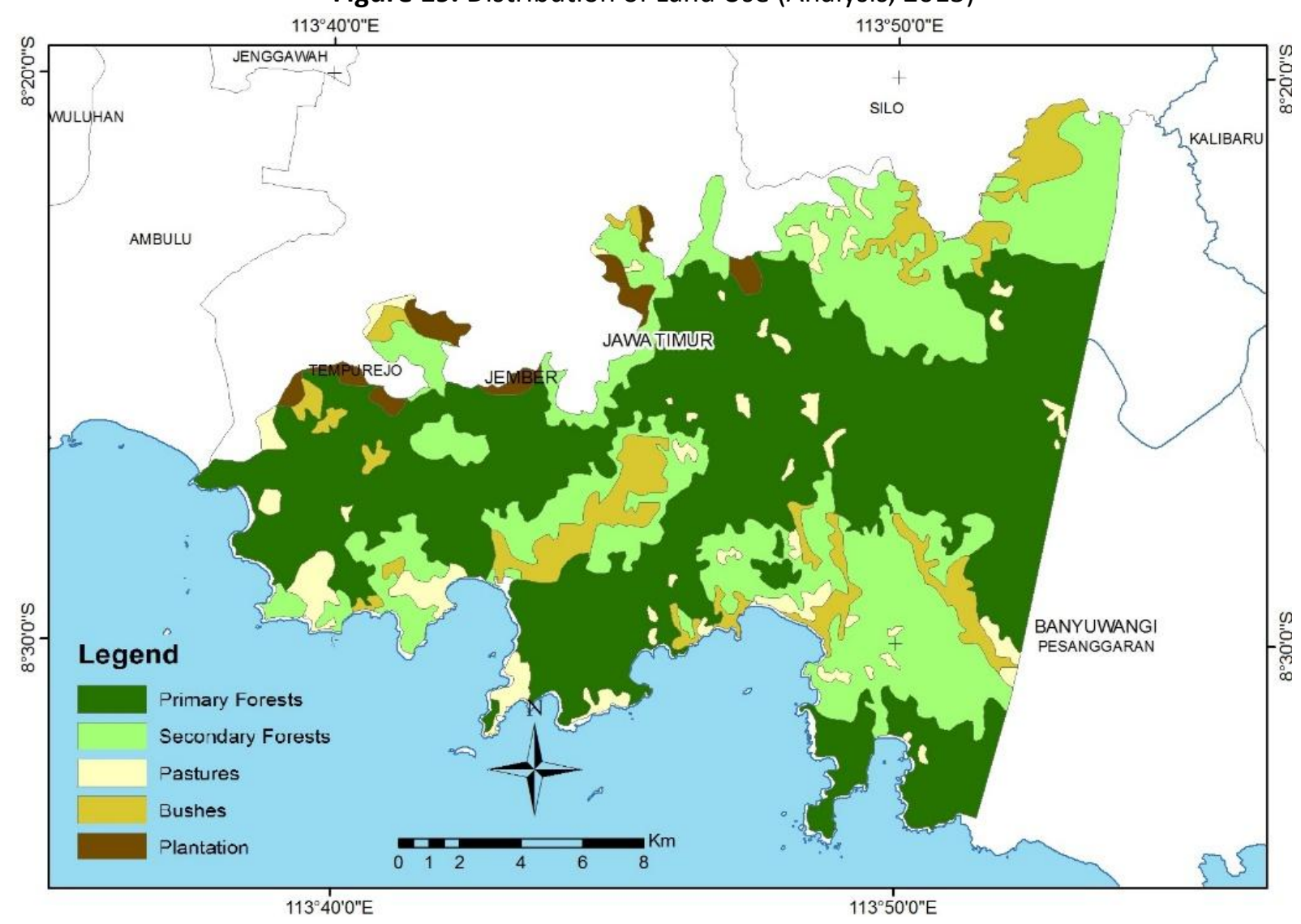

\section{CONCLUSION}

Based on carbon storage identification from ALOS AVNIR satellite data with Meru Betiri National Park as the object, it can be concluded that from vegetation index value approach, vegetation indices that are suitable to Meru Betiri National Park were MSAVI dan IPVI. MSAVI and especially IPVI approach values are more suitable than other vegetation indices for this area because almost $70 \%$ of this area was still forest. IPVI uses Infrared band since it is very suitable in detecting water that is plentifully contained in leaves. The correlation coefficients for MSAVI and IPVI are moderate, i.e., 0.49 and 0.47 respectively. These are due to the availability of field data that was not enough to represent all land coverage in Meru Betiri National 
Park. Other factor that may contribute to the low correlations was the nature of the Indonesian forest that is humid and causes different reflectance number than what it should be. Linear equation that can be used to estimate carbon storage was using MSAVI, NDVI, and RVI vegetation indices.

The equation is Carbon Storage $=41.0621-(199.068 \times \mathrm{MSAVI})+(197.383 \times \mathrm{NDVI})-(2.43022 \times \mathrm{RVI})$ with correlation number $(r)$ of 0.63 and error number of $0.41 \mathrm{~kg} / 100 \mathrm{~m}^{2}$. Using this equation, the estimated carbon storage in Meru Betiri National Park (the area of 34,958 ha) was 3,591,321 tons. By combining several vegetation index variables in estimating carbon storage using linear equation, the correlation value was enhanced better than when using single variable. Exponential equation used to estimate carbon storage using MSAVI and IPVI vegetation indices was Carbon Storage $=0.069 \times\left(\mathrm{e}^{(-235.894 \times \mathrm{IPVN})}+\mathrm{e}^{(3.439 \times \mathrm{MSVn})}\right)$ with correlation number of 0.321 and error number of $0.59 \mathrm{~kg} / 100 \mathrm{~m}^{2}$. Using this equation, the estimated carbon storage in Meru Betiri National Park was 3,921,323 tons. The comparison showed that by combining several variables of vegetation indices will increase the value of the correlation equation significantly.

\section{REFERENCES}

Akumu, C. E., \& McLaughlin, J. W. (2014). Modeling peatland carbon stock in a delineated portion of the Nayshkootayaow river watershed in Far North, Ontario using an integrated GIS and remote sensing approach. Catena, 121, 297-306. http://doi.org/10.1016/j.catena.2014.05.025

Ardiansyah, D. M., \& Buchori, I. (2014). Pemanfaatan Citra Satelit Untuk Penentuan Lahan Kritis Mangrove Di Kecamatan Tugu, Kota Semarang. Geoplanning Journal of Geomatics and Planning, 1(1), 1-12.

Cantarello, E., Newton, A. C., \& Hill, R. A. (2011). Potential effects of future land-use change on regional carbon stocks in the UK. Environmental Science and Policy, 14(1), 40-52. http://doi.org/10.1016/j.envsci.2010.10.001

Elias, \& Wistara, I. N. J. (2009). Inovasi Metodologi dan Metode Estimasi Cadangan Karbon dalam Hutan dalam Rangka Reduced Emissions From Deforestation and Degradation (REDD) Indonesia. In Prosiding Seminar Hasil - Hasil Penelitian IPB (pp. 288-307). Bogor: IPB Bogor.

Filzmoser, P. (2004). A Multivariate Outlier Detection Method. Vienna-Austria.

Hairiah, K., et. al. (2001). Methods for sampling carbon stocks above and below ground. ICRAF Bogor, Indonesia.

Humpenöder, F., et. al. (2013). Effects of land-use change on the carbon balance of 1st generation biofuels: An analysis for the European Union combining spatial modeling and LCA. Biomass and Bioenergy, 56, 166-178. http://doi.org/10.1016/j.biombioe.2013.05.003

Lévesque, J., \& King, D. J. (2003). Spatial analysis of radiometric fractions from high-resolution multispectral imagery for modelling individual tree crown and forest canopy structure and health. Remote Sensing of Environment, 84(4), 589-602.

Lu, D. (2006). The potential and challenge of remote sensing-based biomass estimation. International Journal of Remote Sensing, 27(7), 1297-1328.

Myeong, S., Nowak, D. J., \& Duggin, M. J. (2006). A temporal analysis of urban forest carbon storage using remote sensing. Remote Sensing of Environment, 101(2), 277-282.

Ponce-Hernandez, R., Koohafkan, P., \& Antoine, J. (2004). Assessing carbon stocks and modelling win-win scenarios of carbon sequestration through land-use changes (Vol. 1). Food \& Agriculture Org.

Riaño, D., et. al. (2003). Assessment of different topographic corrections in Landsat-TM data for mapping vegetation types. IEEE Transactions on Geoscience and Remote Sensing , 41(5), 1056-1061.

Rosenqvist, A., et. al. (1999). Remote sensing and the Kyoto protocol: a review of available and future technology for monitoring treaty compliance. In Workshop Report, Ann Arbor, MI, USA (pp. 20-22).

Seo, S. (2006). A review and comparison of methods for detecting outliers in univariate data sets. University of Pittsburgh.

Sohl, T. L., et. al. (2012). A land-use and land-cover modeling strategy to support a national assessment of carbon stocks and fluxes. Applied Geography, 34, 111-124.

Sularso, G. N. M., Hermawan, R., \& Prasetyo, L. B. (2011). Pendugaan Perubahan Cadangan Karbon di Taman Nasional Meru Betiri. In Semiloka Nasional: Implementasi RAN-GRK untuk bidang berbasis Lahan. Bogor: IPB Press. 
Sun, H., et. al. (2015). Increasing the Accuracy of Mapping Urban Forest Carbon Density by Combining Spatial Modeling and Spectral Unmixing Analysis. Remote Sensing, 7(11), 15114-15139. http://doi.org/10.3390/rs71115114

Ulumuddin, Y. I., et. al. (2005). Korelasi stok karbon dengan karakteristik spektral citra landsat: studi kasus gunung papandayan. In Presented on Pertemuan IImiah Tahunan MAPIN XIV, "Pemanfaatan Efektif Pengideraan Jauh Untuk Peningkatan Kesejahteraan Bangsa", Surabaya.

Widayati, A., Ekadinata, A., \& Syam, R. (2005). Land use change in Nunukan: Estimating landscape level carbon stocks through land cover types and vegetation density. Carbon stocks monitoring in Nunukan, East Kalimantan: A spatial and modelling approach. Report from FORMACS project. 